\title{
Criminology and situational prevention
}

\author{
Vincenzo Mastronardi \\ Psychiatrist, Forensic Psychopathologist, Clinical Criminologist Sapienza University of Rome, Director of the \\ Criminology Master I Level Unitelma Sapienza Rome and Director of the Criminology Master II Level International \\ Studies University of Rome (UNINT), Italy
}

\begin{abstract}
The present work brings to light a criminology and a preventative system from a less classic perspective, which does not aim to explain the criminal or the reasons why the act is committed, but rather a theoretical overview that focuses on the setting of the offense and the environmental opportunities that the criminal has taken to commit him. Situational Crime Prevention places attention and works on a set of public and private facilities (such as schools, hospitals, transport systems, shops, shopping malls, small businesses, telephone companies, parks, clubs, entertainment venues, bars and parkings) that create conditions, actions and performance that are potentially suitable and fertile for delinquency.
\end{abstract}

\section{RIASSUNTO}

Il presente lavoro porta alla luce una criminologia e un sistema preventivo letti da una prospettiva meno classica, che non si pone l'obiettivo di spiegare il criminale o le ragioni per cui l'atto illecito viene compiuto, bensì tratta una panoramica teorica che si focalizza sul setting del reato e sull'opportunità ambientale che il reo ha colto per commetterlo. Ecco che le Prevenzione Situazionale Criminologica attenziona e va ad operare su un insieme di strutture pubbliche e private (quali scuole, ospedali, sistemi di trasporto, negozi, centri commerciali, piccola imprenditoria, compagnie telefoniche, parchi, locali, luoghi di divertimento, bar e parcheggi) che vanno a creare circostanze, azioni e prestazioni, tutte potenzialmente idonee e fertili per la realizzazione di delinquenza.

\section{RESUMEN}

El presente trabajo saca a la luz una criminología y un sistema preventivo leídos desde una perspectiva menos clásica, que no pretende explicar el criminal o las razones por las cuales se comete el acto, sino que trata de una visión teórica que enfoca en el escenario de la ofensa y en la oportunidad ambiental que el rey ha capturado para cometerla. Prevención Situacional Criminológica atrae y opera en un conjunto de instalaciones públicas y privadas (como escuelas, hospitales, sistemas de transporte, tiendas, centros comerciales, pequeñas empresas, compañías telefónicas, parques, clubes, lugares de entretenimiento, bares y aparcamientos) que crean condiciones, acciones y rendimiento, todos potencialmente aptos y fértiles para el propósito de la delincuencia.

\section{Introduction}

The human being has always been fascinated by evil and its origins, as always, scholars are prone to the analysis of the criminal figure. Several scholars have dealt with deviance and delinquency; modern criminology begins at the end of the nineteenth century with the theories of Cesare Lombroso, devoted to the physiognomy and the investigation of the cranial abnormalities and how they can explain and classify criminal activities. Of great importance is the psychological-structural approach of Freud: according to the father of psychoanalysis the structures that make up the psyche and the driving forces that animate it would determine the "sense of guilt" of the offender, pre-existing to the commission of the unlawful act and not later to it. It would be the same fraud to derive from the sense of guilt. Durkheim and Merton, on the contrary, propose a sociological approach, according to which the social context (political, historical, geographical, situational) influences the commission of deviating behavior.
In a more comprehensive and synthetic framework, it is possible to identify a causal circle within which individual (morphological, genetic) predispositions affect personal intentions (psychological and character traits) which in turn are confronted with the influence of society (anomy).

\section{Situational Crime Prevention: Definition}

Situational Crime Prevention differs completely from the theoretical perspective of traditional criminology (Clarke and Mayhew, 1980). It uses an analytical methodology of precipitating circumstances in each type of delinquency that, through management or environmental modification, aims to decrease the likelihood of delinquency being implemented. It is not about suppressing deviance through social or bureaucratic progress, but essentially to present it less appetizing in the eyes of those who intend to adhere to it.

The focus is shifted to a new study object, context, and no 
longer the person ("The attempt to explain crime was almost confused with trying to explain the criminal" Ronald Clarke, 1997). Crime prevention techniques aim to improve security in the crime setting by intervening to ensure that a certain unlawful act does not occur (crime control $\neq$ criminal control).

The Routine Activity Theory (Cohen, Felson, 1998) attempts to explain the "predatory crimes" (thefts in homes, snatching) by identifying in space and time the convergence of three elements in consideration of the usual activities that each of us adopt in everyday life (work, shopping, recreational activities, etc.):

1. The presence of a possible target (a suitable target-victim).

2. The absence of a capable guardian (a "controller" that does not necessarily have to be a public security agent).

3. A likely offender (an offender intent on taking advantage of the situation).

In the Figure 1 is the graphical representation of the "Basic Triangle of Crime: the "chemistry" for crime:

\section{Theoretical frameworks}

Before proceeding, it is useful to mention three theoretical models that well introduce the conceptual nucleus of Situational Crime Prevention:

- RATIONAL CHOICE THEORY (Clark e Cornish, 1985 e 1986; from "Crime and Punishment: an economic approach" Becker, 1968). It is based on the assertion that the perpetrators of criminal acts develop the transition to action through a costbenefit assessment decision-making process.

This decision-making process is influenced by: time available, cognitive programming-implementation skills, information available, criminal background.

- LIFETIME-EXPOSURE THEORY (Hindelang, Gottfredson e Garofalo, 1978): Victimological approach according to which demographic characteristics and daily habits (work and recreational activities) affect individual vulnerability.
Victimization experiences are predictable on the basis of lifestyle changes induced by the social placement of individuals. - THEORETICAL MODELS OF CRIME (Brantingham e Brantingham, 1984): linked to the life-exposure and daily habits theory, it rests on three main concepts:

- Nodes: which concern the movement from where and where people move. In these places, crime can develop within the same places or nearby (shops, public places, etc.), depending on the risk of victimization.

- Paths: routes made by people who attend places. In this way, crime maps will be created for different times of the day and for the different days of the week.

- Edges: within which people move outside of their home or work activities.

In addition, there are ecological theories, which show a relationship between the structure of the urban environment and the rates of crime. Urban planning and architectural design affect the security of a territory, increasing the promotion of city welfare and reducing crime. The idea of "defensible space", designed by architect Oscar Newman, was used to plan the design of public housing to entice the same residents to take responsibility for control to discourage predatory crime (urban planning was already proposed by Jacobs in 1961, in a study that correlated crime with network / layout of the streets). Another important name for this type of study is Jeffery (1971), author of the Criminal Prevention Through Environment Design (CPTED) concept of Crime Prevention which applies the concept of "defensible space" also to schools and commercial areas and had extremely positive results using the "problem-oriented policing" approach (Goldstein, 1979).

\section{Opportunity Reduction Techniques}

One of the most widespread systematization of these techniques dates to 2006 and has been drafted by Clarke and Newman when these techniques are grouped into five motivators that reduce the chances of crime: increase efforts, increase risks, reduce benefits, reduce provocations and remove excuses.

\section{SUITABLE TARGET (YES):}

person, object, place.

VIVA (value, inertia, visibility, accessibility) e CRAVED (conceivable, removable, available, precious, enjoyable, sellable)

\section{LIKELY OFFENDER (YES):}

The assessment of the aggressor's situation will determine whether the crime will take place.
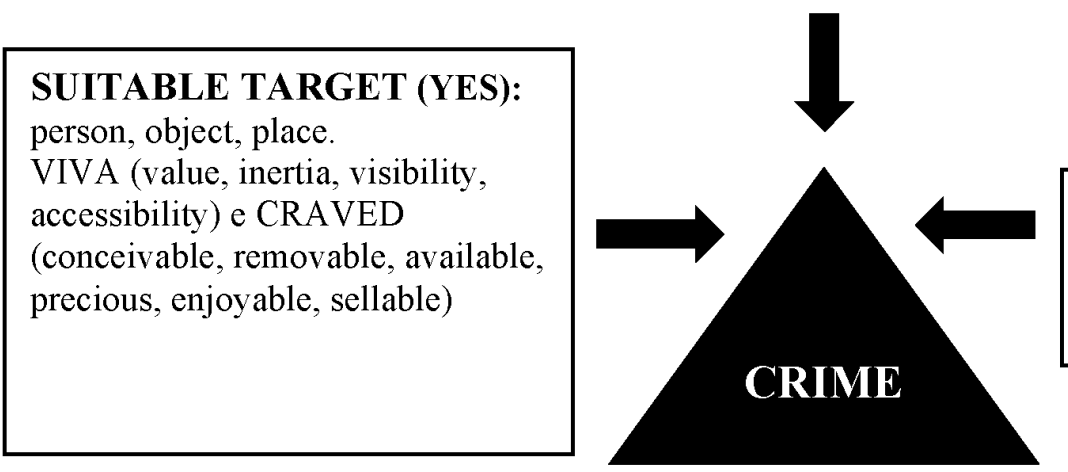

CAPABLE GUARDIAN (NO):

Order Forces, Private Watch, Neighborhood Volunteers, Door \& Home Owners, Cameras

\section{Figure 1.}


Here are some examples:

Increase your efforts:

1. Make your targets less vulnerable

- Anti-theft panels

- Safe packaging

2. Check accesses

- Telephones in the inputs

- Access by electronic card

- Luggage control

3. "Mislead" the authors

- Close the streets

- Separate services for men and women

- Location of public places

Increasing risks:

1. Increase protection

- Go outside in group and bring the cell phone

- Neighborhood watch (neighborhood support and attention)

2. Increase natural surveillance

- Increase urban lighting

- Defensive space

- Delimitation of spaces

3. Reduce anonymity

- Recognition cards for taxi drivers

- Identification of the car

- School Uniforms

4. Use Space Managers

- Cameras on buses

- Increase of staff in stores

- Parking fee

5. Increase Formal Surveillance

- Cameras at the traffic light

- Alarm systems

- Security guards

Reduce Benefits:

1. Hiding the Goals

- Parkings away from the main road

- Neutral telephone directories by gender

2. Disassemble Markets

- Mandatory license for street vendors

- Checking the pawns

Reduce the provocation:

1. Reduce frustration and stress

- Efficient and educated codes

- Increase seats

- Moderate the volume of music

2. Neutralize peer pressure

- "Only stupid people drink and drive"

- "It is OK to say NO"

- Separate problematic students

Remove excuses:

1. Facilitate compliant behaviors

- Easy outbound control of libraries

- Public bathrooms

- Waste bins

\section{Subdivision of prevention techniques based on the specific nature of the offense}

Based on theories of crime prevention, as Clarke himself expressed, the techniques of crime reduction are not all valid and applicable to any type of crime: there are some valid for certain crimes that may instead be bankrupt for other offenses. Let's look at some valid techniques (or the merger of more than one) broken down by types of offense, bringing some statistical or historical data that confirms their validity.

Theft can be considered a predatory offense with a low emotional component (it is statistically less likely to commit a theft to someone with intimidation or rebellion), then it should be treated with deterrence and control techniques to increase the risks and reduce the criminal's benefits.

With regard to theft, the most appropriate and effective prevention techniques are as follows:

- Increase natural monitoring (pruning trees and gardens, indoor lighting of shops and banks, outdoor lighting of streets and apartments).

- Increase Formal Surveillance (Police, Security Guards, Military Electronic Surveillance Circuits)

While some complementary reduction techniques might be: Access Control, Exit Check, Goal Removal, Black Market Disaggregation.

At a statistical level, in the period from June to October 2008 in Italy, thanks to a campaign promoted by the Government, security in banks has increased through the installation of more sophisticated anti-theft devices and the increase of authority figures (Private Guards). During this period, banks had a $26.7 \%$ drop in theft.

Sexual abuse can be considered as a crime that is highly related to other types of offense: those who perpetrate a type of offense, usually minor (homicide, theft, aggression, spaceship), can find fertile ground to overcome their criminal intent to harm the victim, through rape in its various forms. In this case, more than in other offenses, the role of the victim for the conduct of the offender is decisive. Studies on victimism can lead to more awareness of the most at risk.

With regard to sexual violence, a specific risk reduction technique could be:

- Control of alcohol and drugs (many sexual abuse of women's damages occur in places where frequent use of drugs is common; limiting the use has the dual effect: to keep the threshold of potential casualties high and keep the instincts of the potential offender rationally vigilant).

While Complementary Reduction Techniques could be:

- Increasing protection (Avoiding dangerous roads, types of potential victims should always go out in groups, keep an alert status in potentially dangerous situations),

- Establish rules, make known the instructions (programs by government authorities that clearly state codes and sanctions). Finally, let's consider the murder.

Compared with other types of crime, homicide, in addition to being the crime of par excellence, has different connotations as psychopathological features are virtually absent in crimes such as theft or robbery and statistically less relevant in crimes such as sexual abuse, stalking etc. About $98 \%$ of those who have been charged with murder have one or more personality disorders. It is obvious that in this case basic prevention should be shifted to society or to the individual rather than to the environment, and that some embankment techniques can also lead to the displacement phenomenon. 


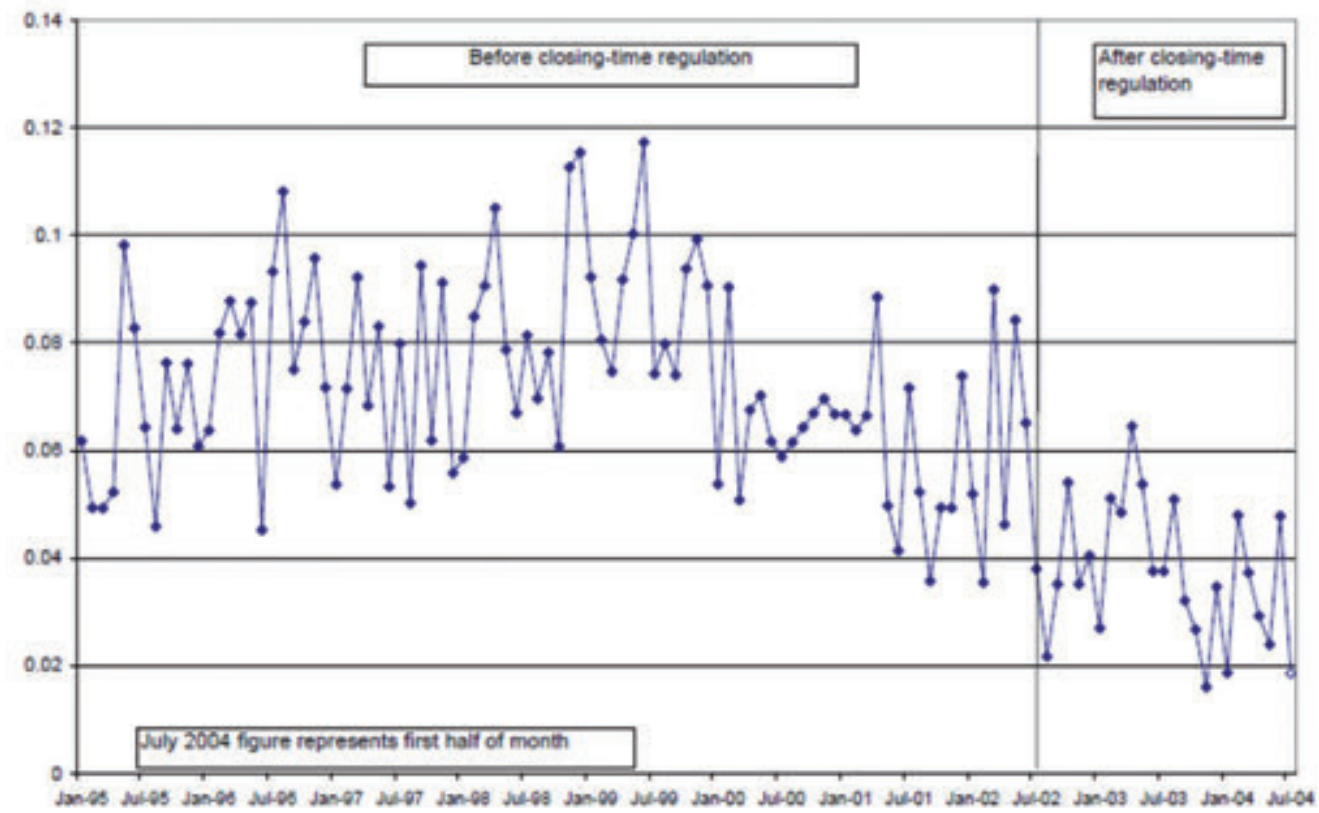

Figure 2.

In this case, the specific risk reduction techniques:

- Reduce frustration and stress (those who have highly aggressive biological predisposition can be affected by stressors, from row to chest to car traffic, to actual or alleged injustice, and lead to highly behaviors aggressive)

- Reduce emotional provocations

Regarding the Related Techniques we find:

- Avoid quarrels

- Control of alcohol and drugs

Statistics show that in February 2004, in Diadema, a city of Brazil with 386,000 inhabitants, new laws were implemented, thanks to the fusion of ideas from the Federal University of Sao Paulo and government authorities. It was forbidden to sell alcohol after 23.00. The mayor of Diadema set up a crime map of the city that evaluated the hours between 23:00 and 6:00 as the most dangerous in terms of aggression ( $45 \%$ of the calls for aggression were

Correspondence: Vincenzo Mastronardi.

E-mail: vincenzo.mastronardi@uniroma1.it

Key words: Situational crime prevention; opportunity; crime opportunity theory; safety; prevention.

Parole chiavi: Prevenzione situazionale criminologica; opportunità; teoria di opportunità del crimine; sicurezza; prevenzione.

Palabras clave: Prevención situacional criminológica; oportunidad; teoría de la oportunidad del crimen; seguridad; prevención.

Received for publication: 21 July 2016

Revision received: 10 November 2016.

Accepted for publication: 4 April 2017

C Copyright V. Mastronardi, 2017

Licensee PAGEPress, Italy

Rivista di Psicopatologia Forense, Medicina Legale, Criminologia 2017: 22:31-34 in this timetable) and murders (in neighborhoods high concentration of bar).

After the implementation of the Alcohol Law, the city suffered a dramatic decline in violence against women and murders. The data are statistically significant since in July 2002- July 2004, about 273 murders were prevented.

Figure 2 show the homicide rates before and after law enforcement.

\section{References}

BRANTINGHAM P., BRANTINGHAM P. (1984), Crime Emergence and Simulation Modeling: modeling crime space, Institute for Canadian Urban Research Studies (ICURS)

CLARKE R.V., NEWMAN G.R. (2006), Outsmarting the Terrorists, Greenwood Publishing Group.

CLARKE R.V. (1997), Situational Crime Prevention: Successful Case Studies, 2nd Edition, Albany, NY: Harrow \& Heston, pp. 2-43.

CORNISH D., CLARKE R.V. (1986), "Introduction" in The Reasoning Criminal. Cornish, Derek and Ronald Clarke (eds.). New York: Springer-Verlag. pp. 1-16.

FELSON M. (1998), Crime and Everyday Life, Second Edition. Thousand Oaks, CA: Pine Forge Press.

GOLDSTEIN H. (1979), Problem-Oriented Policing.

HINDELANG M.J., GOTTFREDSON M.R., GAROFALO J. (1978), Victims of personal crime: An empirical foundation for a theory of personal victimization. Cambridge, MA: Ballinger. 